\title{
Mithracinae (Decapoda: Brachyura) from the Brazilian coast: Review of the geographical distribution and comments on the biogeography of the group
}

Douglas Fernandes Rodrigues Alves, Samara de Paiva Barros-Alves, Gustavo Monteiro Teixeira and Valter José Cobo

(DFRA, SPBA) Universidade Estadual Paulista, UNESP, Departamento de Zoologia, Instituto de Biociências. Distrito de Rubião Junior, s/n, 18618-970, Botucatu, São Paulo, Brasil. (DFRA) E-mail: alvesdfr@ibb.unesp.br

(GMT) Universidade Estadual de Londrina, UEL, Departamento de Biologia Animal e Vegetal. 86051980, Londrina, Paraná, Brasil.

(VJC) Universidade de Taubaté, UNITAU, Laboratório de Biologia Marinha, LabBMar, Instituto de Biociências. 12030-180, Taubaté, São Paulo, Brasil.

\section{Abstract}

\begin{abstract}
The geographical distribution of marine organisms, as a result of complex natural processes through geological time, has been changed, sometimes drastically, by species introductions. Instances of species introduction have been recorded worldwide, and the Brazilian coast is no exception. The present review provides an update of the geographical distribution of members of the brachyuran subfamily Mithracinae along the Brazilian coast. Of the 30 species of this subfamily recorded from Brazilian waters, the known geographical limits of more than 17 have been extended in recent decades. The records compiled here demonstrate the great importance of the Amazon River outflow on the geographical distribution of members of Mithracinae, acting as a biogeographical barrier for some species.
\end{abstract}

Key words: Amazon River, Majoidea, provinces, spider crabs.

\section{Introduction}

The Brazilian marine fauna was poorly known until the mid-XIX century, when the great oceanographic expeditions carried out collections along the Brazilian coast (Holthuis, 1991). Most of these expeditions focused on the north-northeastern and south coast of Brazil. Some of these scientific voyages, including the "United States Exploring Expedition" (1838-1842), "Novara" (1857-
1859), "Hassler" (1872), "Albatross" (1888), "Branner-Agassiz" (1899), and "Terra Nova" (1913), also sampled off the southeastern Brazilian coast. Expeditions including the "Santa Maria" (1925), "Calypso" (1961-62) and "Emilia" (1966) also made important contributions to knowledge of the Brazilian marine fauna (Melo, 1985).

Among more-recent expeditions, the Executive Group for Industrial Fisheries Development (GEDIP) of the state of Rio 
Grande do Sul, the Oceanographic Institute of the University of São Paulo (IOUSP) and "Oceanography of the Internal Platform of São Sebastião" (OPISS) developed extensive research projects. In addition, the "Living Resources of the Exclusive Economic Zone" (REVIZEE) program, which evaluates the living resources of the Brazilian exclusive economic zone, had as a main goal to list the species of this exclusive economic zone. Under this program, many scientific cruises resulted in several important reviews of the geographical and ecological distribution of decapod crustaceans off the Brazilian coast (e.g. Coelho-Filho, 2002; 2006; Nucci et al., 2004; Ramos-Porto et al., 2000; 2002; Silva et al., 2001; Torres et al., 2002; Viana et al., 2002; Viana et al., 2003).

The infraorder Brachyura includes 38 superfamilies with 93 families worldwide $(\mathrm{Ng}$ et al., 2008), with approximately 300 recent species recorded from the Brazilian coast (Melo, 1998). About 10\% of these crab species are representatives of the superfamily Majoidea Samouelle, 1819, family Majidae Samouelle, 1819, subfamily Mithracinae MacLeay, 1838 (Ng et al., 2008). These species show different distribution patterns, ranging from small stretches to the entire coast of Brazil. The species of Mithracinae can be found from the intertidal to more than 1000 meters deep, most commonly on hard substrata (Melo, 1998).

The distribution patterns of crabs are mainly associated with variations of environmental features including salinity, temperature, sediment grain size and organicmatter content (Fransozo et al., 1992; Santos et al., 1994; Pinheiro et al., 1996).

Knowledge of the direction of currents and the characteristics of the water masses along the Brazilian coast are important for understanding the distribution patterns shown by these majoids. The Brazilian coast receives the influence of three main currents (Fig. 1A): the Brazil Current; the North Brazilian Current, also called the Guiana Current; and the Malvinas Current, also called the Falkland Current. The North Brazilian Current flows south to north, carrying the Atlantic Ocean
Sub-Surface Water (AOSS) to the northeast, with temperatures between $24^{\circ}$ and $28^{\circ} \mathrm{C}$, salinity around 36, and low concentrations of dissolved nutrients. The Brazilian Current flows north to south; the water masses of this current are mixed and originate a low-nutrient water mass, with temperatures higher than $20^{\circ} \mathrm{C}$, and salinity higher than 36 , the socalled Tropical Water (TW). The Malvinas Current flows over the continental shelf from south to north, carrying nutrient-rich waters, with temperatures ranging from $6^{\circ}$ to $13^{\circ} \mathrm{C}$, and salinity from 33 to 34 . The influence of the Malvinas Current is perceptible as far as the Cabo Frio region off the northeastern coast of Rio de Janeiro State (Melo, 1985; CastroFilho and Miranda, 1998).

Besides TW and AOSS, two other water masses are present, with smaller or larger volumes over the Brazilian continental shelf: South Atlantic Central Water (SACW) and Coastal Water (CW). The SACW is a cold water mass, with temperatures below $20^{\circ} \mathrm{C}$, relatively low salinity ranging from 34.6 to 36, and high nutrient content; while the $\mathrm{CW}$ is formed by the mixture of continental drainage water and the SACW and TW and/ or AOSS. Mainly because of the presence of fluvial discharges, the CW has low salinity and high nutrient concentrations, as reported for the regions of the Amazon basin and the southern Brazilian coast, under the influence of the Rio da Prata (Castro-Filho and Miranda, 1998). Although other important rivers such as the São Francisco and the Parnaíba enter in the Atlantic along the Brazilian coast, their discharge does not exceed $2 \%$ of the mean discharge recorded for the Amazon River.

The Brazilian coast is divided into three biogeographical provinces, according to Boschi (2000): the Magellan Province in the Atlantic Ocean, from a Patagonian region towards north Argentina, deflects from the continent at latitude 43-44\% (Rawson, Chubut, Argentina) going north and reaches $35^{\circ} \mathrm{S}$ at a distance of $100-150 \mathrm{~km}$ from the coast, with a depth of 60-200 m; the Argentinean Province, from 43-44oS (Rawson, Chubut, Argentina) to $23^{\circ} \mathrm{S}$ (Cabo Frio, Rio de Janeiro); and the 


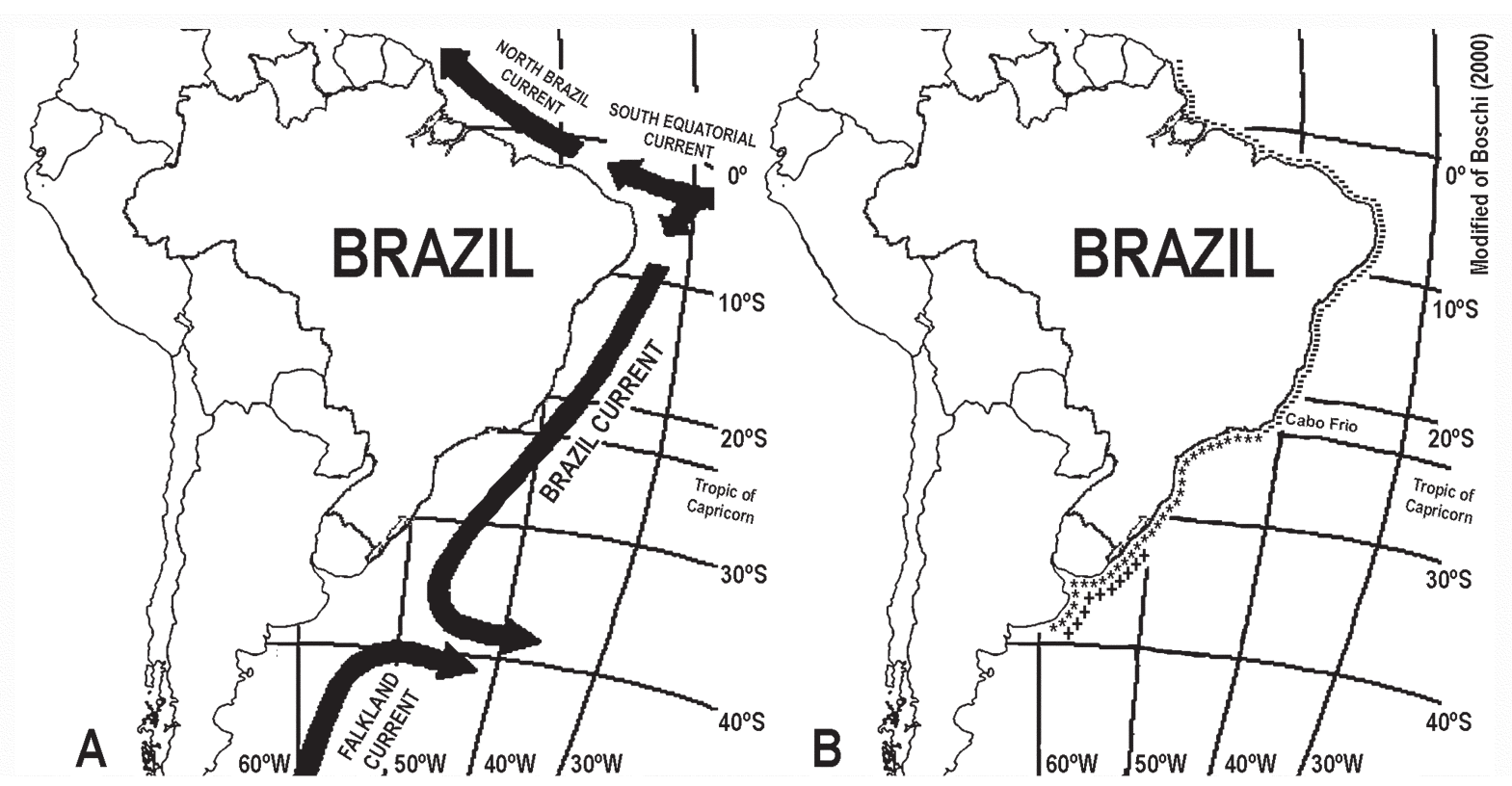

Figure 1. (A) main currents along the coast of Brazil; (B) biogeographical provinces along the coast of Brazil. - = Brazilian Province; ${ }^{*}=$ Argentinean Province; + = Magellan Province.

Brazilian Province, from $23^{\circ} \mathrm{S}$ (Cabo Frio, Rio de Janeiro) to 8056'N (Orinoco River, Venezuela); the Argentinean and Brazilian provinces are separated by a biogeographical barrier in the Cabo Frio region (Fig. 1B).

The Cabo Frio zone, located on the northeastern coast of Rio de Janeiro State, is a cold-water upwelling area that acts as a biological filter for thermophilic species. However, the influence of upwelling is variable, especially as a function of wind direction (Ikeda et al., 1974; Ikeda, 1976; Matsuura, 1986).

The ability of a species to cross this barrier seems to depend on its tolerance to the range of seasonal environmental variations (Melo, 1990). In general, marine biogeographical barriers are not definitive, because eurybathic species can ascend or descend, in depth, following their preferred isotherm (Hedgpeth, 1957). Therefore, barriers can act as a filter, allowing some species to pass. The efficiency of a barrier also seems to depend on the particular part of the fauna considered, because the barrier may be efficient for some groups and unimportant for others, even fostering their dispersal (Melo-Filho, 1997).

The geographical distribution of marine organisms, resulting from complex natural processes over geological time, has been changed, sometimes drastically, by the introduction of exotic species, as reported for many locations worldwide (Tavares and Amouroux, 2003; Silva et al., 2004). Several accounts of species-introduction events, as well as extensions of geographical distribution, have been reported for crustaceans along the Brazilian coast (e.g. Melo, 1990; Melo et al., 2000; Ramos-Porto et al., 2000; Targino et al., 2001; Cobo et al., 2002; Almeida et al., 2003; Bezerra et al., 2005; Alves et al., 2006). Despite these reports, studies that review the geographical distribution of some groups of decapods on the Brazilian coast are still relatively few, limiting the comprehension of the present extent of the biota along this coast.

The present investigation provides an update of the geographical distribution of the crabs of the subfamily Mithracinae MacLeay, 1838 (Decapoda, Brachyura) on the Brazilian coast, and discusses the main features that must determine the distributional patterns of these species.

\section{Material and Methods}

Bibliographic searches covered especially publications that appeared after 1996, when the "Manual de Identificação dos Brachyura 
(Caranguejos e Siris) do Litoral Brasileiro", was published by Prof. Dr. Gustavo Augusto Schmidt de Melo. Despite the fact that this important publication is a major review of the geographical distribution of brachyuran crabs found in Brazilian waters, references earlier than 1996 were also reviewed.

The searches were carried out in the following indexes: ASFA, Biological Abstracts, and Zoological Record. The keywords used were the following: Mithracidae, Mithracinae, Ala, Coelocerus, Cyclocoeloma, Cyphocarcinus, Leptopisa, Macrocoeloma, Micippa, Microphrys, Mithraculus, Mithrax, Nemausa, Paranaxia, Picroceroides, Stenocionops, Teleophrys, Thoe and Tiarinia. All available articles dealing with communities, assemblages, or lists of species of brachyuran crabs, and treating any part of the Brazilian coast were also checked.

All published records in which the subfamily Mithracinae appeared were checked for each state and the oceanic islands (São Pedro-São Paulo Archipelago, Rocas Atoll, Fernando de Noronha, Trindade and Martin Vaz).

The taxonomic status and validity of the species of brachyuran crabs in this study are based generally on $\mathrm{Ng}$ et al. (2008). Although $\mathrm{Ng}$ et al. (2008) reported that Mithrax tortugae Rathbun, 1920 is a junior synonym of Mithrax hispidus (Herbst, 1790), here we follow the conclusions of Windsor and Felder (2009) who, based on analysis of three mitochondrial genes (12S, $16 \mathrm{~S}$ and COI), validated $M$. tortugae. According to $\mathrm{Ng}$ et al. (2008), the genus Hemus A. Milne-Edwards, 1875 belongs to the subfamily Planoterginae Śtevcic, 1991, but as asserted by Windsor and Felder (2011) in their molecular phylogenetic analyses, the genus Hemus should be restored to Mithracinae sensu Ng et al. (2008).

Species of Mithracinae from the Brazilian coast were grouped according to the Jaccard similarity index, based on their presence or absence, by the UPGMA (Unweighted Pair Group Method with Arithmetic Mean) cluster method (Zar, 2010), to identify groups according to the similarity in species composition by state or island.
Results

The species of Mithracinae recorded for the Brazilian coast (Tab. 1) are:

Hemus cristulipes A. Milne-Edwards, 1875 - Geographic distribution: Western Atlantic - North and South Carolina, Florida, Gulf of Mexico, Antilles and Brazil (Fernando de Noronha and from Maranháo to Rio de Janeiro) (Melo, 1996).

Leptopisa setirostris (Stimpson, 1871) Geographic distribution: Western Atlantic Florida, Antilles, Venezuela and Brazil (from Maranhão to Espírito Santo) (Melo, 1996).

Macrocoeloma camptocerum (Stimpson, 1871) - Geographic distribution: Western Atlantic - North Carolina, Florida, Gulf of Mexico and Brazil (from Amapá to Maranhão and Ceará) (Melo, 1998; Coelho-Filho, 2006).

Macrocoeloma concavum Miers, 1886 Geographic distribution: Western Atlantic Antilles and Brazil (Fernando de Noronha and from Maranhão to Bahia) (Melo, 1996).

Macrocoeloma eutheca (Stimpson, 1871) - Geographic distribution: Western Atlantic - From North Carolina to Florida, Gulf of Mexico, Antilles, Central America and Brazil (from Maranhão to Espírito Santo) (Melo, 1996).

Macrocoeloma laevigatum (Stimpson, 1860) - Geographic distribution: Western Atlantic - Florida, Gulf of Mexico, Antilles and Brazil (from Pará to Alagoas and Bahia) (Melo, 1998; Serejo et al., 2006).

Macrocoeloma nodipes (Desbonne, in Desbonne \& Schramm, 1867) - Geographic distribution: Western Atlantic - Bermuda, North Carolina, Florida, Gulf of Mexico and Brazil (Fernando de Noronha) (Rathbun, 1925).

Macrocoeloma septemspinosum (Stimpson, 1871) - Geographic distribution: Western Atlantic - South Carolina do Sul, Florida, Gulf of Mexico and Brazil (Fernando de Noronha and from Ceará to Espírito Santo) (Melo, 1998; Coelho-Filho, 2006; Serejo et al., 2006).

Macrocoeloma subparallelum (Stimpson, 1860) - Geographic distribution: Western 
Table 1. List of species of Mithracinae by state and oceanic islands off the coast of Brazil. States: AP = Amapá; PA = Pará; $\mathrm{MA}=$ Maranhão; $\mathrm{PI}=$ Piauí; $\mathrm{CE}=$ Ceará; $\mathrm{RN}=$ Rio Grande do Norte; $\mathrm{AR}=$ Rocas; $\mathrm{PB}=\mathrm{Paraíba}$; PE = Pernambuco; FN = Fernando de Noronha; PS = Archipelago of the São Pedro-São Paulo; AL = Alagoas; SE = Sergipe; BA = Bahia; ES = Espírito Santo; RJ = Rio de Janeiro; SP = São Paulo; PR = Paraná; SC = Santa Catarina; RS = Rio Grande do Sul.

\begin{tabular}{|c|c|c|c|c|c|c|c|c|c|c|c|c|c|c|c|c|c|c|c|c|}
\hline Species & $\mathrm{AP}$ & PA & MAA & PI & $\mathrm{CE}$ & $\mathrm{RN}$ & $\mathrm{AR}$ & $\mathrm{PB}$ & PE & $\mathrm{FN}$ & PS & $\mathrm{AL}$ & SE & BA & ES & RJ & SP & PR & SC & $\mathrm{RS}$ \\
\hline Hemus cristulipes & & & $\mathrm{X}$ & $\mathrm{X}$ & $\mathrm{X}$ & $\mathrm{X}$ & & $\mathrm{X}$ & $\mathrm{X}$ & $\mathrm{X}$ & & $\mathrm{X}$ & $\mathrm{X}$ & $\mathrm{X}$ & $\mathrm{X}$ & $\mathrm{X}$ & & & & \\
\hline Leptopisa setirostris & & & $\mathrm{X}$ & $\mathrm{X}$ & $\mathrm{X}$ & $\mathrm{X}$ & & $\mathrm{X}$ & $\mathrm{X}$ & & & $\mathrm{X}$ & $\mathrm{X}$ & $\mathrm{X}$ & $\mathrm{X}$ & & & & & \\
\hline Macrocoeloma camptocerum & $\mathrm{X}$ & $\mathrm{X}$ & $\mathrm{X}$ & & $\mathrm{X}$ & & & & & & & & & & & & & & & \\
\hline Macrocoeloma concavum & & & $\mathrm{x}$ & $\mathrm{X}$ & $\mathrm{x}$ & $\mathrm{X}$ & & $\mathrm{X}$ & $\mathrm{X}$ & $\mathrm{X}$ & & $\mathrm{X}$ & $\mathrm{X}$ & $\mathrm{X}$ & & & & & & \\
\hline Macrocoeloma eutheca & & & $\mathrm{X}$ & $\mathrm{X}$ & $\mathrm{X}$ & $\mathrm{X}$ & & $\mathrm{X}$ & $\mathrm{X}$ & & & $\mathrm{X}$ & $\mathrm{X}$ & $\mathrm{X}$ & $\mathrm{X}$ & & & & & \\
\hline Macrocoeloma laevigatum & & $\mathrm{X}$ & $\mathrm{X}$ & $\mathrm{X}$ & $\mathrm{X}$ & $\mathrm{X}$ & & $\mathrm{X}$ & $\mathrm{X}$ & & & $\mathrm{X}$ & & $\mathrm{X}$ & & & & & & \\
\hline Macrocoeloma nodipes & & & & & & & & & & $\mathrm{X}$ & & & & & & & & & & \\
\hline Macrocoeloma septemspinosum & & & & & $\mathrm{X}$ & $\mathrm{X}$ & & $\mathrm{X}$ & $\mathrm{X}$ & $\mathrm{X}$ & & $\mathrm{X}$ & $\mathrm{X}$ & $\mathrm{X}$ & $\mathrm{X}$ & & & & & \\
\hline Macrocoeloma subparallelum & $\mathrm{X}$ & $\mathrm{X}$ & $\mathrm{X}$ & $\mathrm{X}$ & $\mathrm{X}$ & $\mathrm{X}$ & & $\mathrm{X}$ & $\mathrm{X}$ & $\mathrm{X}$ & & $\mathrm{X}$ & $\mathrm{X}$ & $\mathrm{X}$ & $\mathrm{X}$ & & & & & \\
\hline Macrocoeloma trispinosum & & $\mathrm{X}$ & $\mathrm{X}$ & $\mathrm{X}$ & $\mathrm{X}$ & $\mathrm{X}$ & & $\mathrm{X}$ & $\mathrm{X}$ & $\mathrm{X}$ & & $\mathrm{X}$ & $\mathrm{X}$ & $\mathrm{X}$ & $\mathrm{X}$ & $\mathrm{X}$ & $\mathrm{X}$ & & & \\
\hline Microphrys antillensis & & & & & & & & $\mathrm{X}$ & $\mathrm{X}$ & & & $\mathrm{X}$ & $\mathrm{X}$ & $\mathrm{X}$ & $\mathrm{X}$ & $\mathrm{X}$ & $\mathrm{X}$ & & & \\
\hline Microphrys bicornutus & & & $\mathrm{X}$ & $\mathrm{X}$ & $\mathrm{X}$ & $\mathrm{X}$ & $\mathrm{X}$ & $\mathrm{X}$ & $\mathrm{X}$ & $\mathrm{X}$ & & $\mathrm{X}$ & $\mathrm{X}$ & $\mathrm{X}$ & $\mathrm{X}$ & $\mathrm{X}$ & $\mathrm{x}$ & $\mathrm{X}$ & $\mathrm{X}$ & $\mathrm{X}$ \\
\hline Microphrys garthi & & & & & & & & $\mathrm{X}$ & $\mathrm{X}$ & & & $\mathrm{X}$ & $\mathrm{X}$ & $\mathrm{X}$ & $\mathrm{X}$ & $\mathrm{X}$ & & & & \\
\hline Microphrys interruptus & & & $\mathrm{X}$ & $\mathrm{X}$ & $\mathrm{X}$ & $\mathrm{X}$ & & $\mathrm{X}$ & $\mathrm{X}$ & $\mathrm{X}$ & & $\mathrm{X}$ & & & & & & & & \\
\hline Mithraculus coryphe & & & & & $\mathrm{X}$ & $\mathrm{X}$ & & $\mathrm{X}$ & $\mathrm{X}$ & $\mathrm{X}$ & & $\mathrm{X}$ & $\mathrm{X}$ & $\mathrm{X}$ & $\mathrm{X}$ & $\mathrm{X}$ & $\mathrm{X}$ & & & \\
\hline Mithraculus forceps & & & $\mathrm{X}$ & $\mathrm{X}$ & $\mathrm{X}$ & $\mathrm{X}$ & $\mathrm{X}$ & $\mathrm{X}$ & $\mathrm{X}$ & $\mathrm{X}$ & $\mathrm{X}$ & $\mathrm{X}$ & $\mathrm{X}$ & $\mathrm{X}$ & $\mathrm{X}$ & $\mathrm{X}$ & $\mathrm{X}$ & & & \\
\hline Mithraculus sculptus & & & & & & $\mathrm{X}$ & & $\mathrm{X}$ & $\mathrm{X}$ & $\mathrm{X}$ & & $\mathrm{X}$ & $\mathrm{X}$ & $\mathrm{X}$ & & & $\mathrm{X}$ & & & \\
\hline Mithrax besnardi & & & & & & & & & & & & & & & & & & & & $\mathrm{X}$ \\
\hline Mithrax braziliensis & & & & $\mathrm{X}$ & $\mathrm{X}$ & $\mathrm{X}$ & & $\mathrm{X}$ & $\mathrm{X}$ & & & $\mathrm{X}$ & $\mathrm{X}$ & $\mathrm{X}$ & $\mathrm{X}$ & $\mathrm{X}$ & $\mathrm{X}$ & & & \\
\hline Mithrax hemphilli & & & $\mathrm{X}$ & $\mathrm{X}$ & $\mathrm{X}$ & $\mathrm{X}$ & $\mathrm{X}$ & $\mathrm{X}$ & $\mathrm{X}$ & & & $\mathrm{X}$ & $\mathrm{X}$ & $\mathrm{X}$ & $\mathrm{X}$ & $\mathrm{X}$ & & & & \\
\hline Mithrax hispidus & $\mathrm{X}$ & $\mathrm{X}$ & $\mathrm{X}$ & $\mathrm{X}$ & $\mathrm{X}$ & $\mathrm{X}$ & & $\mathrm{X}$ & $\mathrm{X}$ & & & $\mathrm{X}$ & $\mathrm{X}$ & $\mathrm{X}$ & $\mathrm{X}$ & $\mathrm{X}$ & $\mathrm{X}$ & & $\mathrm{X}$ & \\
\hline Mithrax tortugae & & $\mathrm{X}$ & & & & & & & $\mathrm{X}$ & & & $\mathrm{X}$ & & $\mathrm{X}$ & $\mathrm{X}$ & $\mathrm{X}$ & $\mathrm{X}$ & & $\mathrm{X}$ & \\
\hline Mithrax verrucosus & & & & & & & $\mathrm{X}$ & & & $\mathrm{X}$ & & & & & & & $\mathrm{X}$ & & & \\
\hline Nemausa acuticornis & $\mathrm{X}$ & $\mathrm{X}$ & $\mathrm{X}$ & $\mathrm{X}$ & $\mathrm{X}$ & $\mathrm{X}$ & $\mathrm{X}$ & $\mathrm{X}$ & $\mathrm{X}$ & $\mathrm{X}$ & & $\mathrm{X}$ & $\mathrm{X}$ & $\mathrm{X}$ & $\mathrm{X}$ & $\mathrm{X}$ & $\mathrm{X}$ & & & \\
\hline Nemausa cornuta & $\mathrm{X}$ & $\mathrm{X}$ & $\mathrm{X}$ & $\mathrm{X}$ & $\mathrm{X}$ & $\mathrm{X}$ & $\mathrm{X}$ & $\mathrm{X}$ & $\mathrm{X}$ & $\mathrm{X}$ & & $\mathrm{X}$ & $\mathrm{X}$ & $\mathrm{X}$ & $\mathrm{X}$ & & & & & \\
\hline Picroceroides tubularis & $\mathrm{X}$ & $\mathrm{X}$ & $\mathrm{X}$ & $\mathrm{X}$ & $\mathrm{X}$ & $\mathrm{X}$ & $\mathrm{X}$ & $\mathrm{X}$ & $\mathrm{X}$ & $\mathrm{X}$ & & $\mathrm{X}$ & & $\mathrm{X}$ & $\mathrm{X}$ & & & & & \\
\hline Stenocionops furcatus & & & & & $\mathrm{X}$ & $\mathrm{X}$ & & $\mathrm{X}$ & $\mathrm{X}$ & & & $\mathrm{X}$ & $\mathrm{X}$ & $\mathrm{X}$ & $\mathrm{X}$ & $\mathrm{X}$ & $\mathrm{X}$ & $\mathrm{X}$ & $\mathrm{X}$ & $\mathrm{X}$ \\
\hline Stenocionops spinimanus & & $\mathrm{X}$ & & & & $\mathrm{X}$ & & & & $\mathrm{X}$ & & & & & & $\mathrm{X}$ & $\mathrm{X}$ & & & \\
\hline Stenocionops spinosissimus & $\mathrm{X}$ & & & & & $\mathrm{X}$ & & $\mathrm{X}$ & $\mathrm{X}$ & $\mathrm{X}$ & & $\mathrm{X}$ & $\mathrm{X}$ & $\mathrm{X}$ & $\mathrm{X}$ & $\mathrm{X}$ & $\mathrm{X}$ & $\mathrm{X}$ & $\mathrm{X}$ & $\mathrm{X}$ \\
\hline Teleophrys ornatus & & & & & & & & & & $\mathrm{X}$ & & & & $\mathrm{X}$ & & & $\mathrm{X}$ & & & \\
\hline Teleophrys pococki & & & & & & & & & $\mathrm{X}$ & $\mathrm{X}$ & & $\mathrm{X}$ & & $\mathrm{X}$ & & & & & & \\
\hline Thoe aspera & & & & & & & & & $\mathrm{X}$ & & & $\mathrm{X}$ & & & & & & & & \\
\hline
\end{tabular}

Atlantic - Gulf of Mexico, Antilles, Venezuela and Brazil (Fernando de Noronha and from Amapá to Espírito Santo) (Melo, 1996).

Macrocoeloma trispinosum (Latreille, 1825) - Geographic distribution: Western Atlantic - North Carolina, Bermuda, Florida, Gulf of Mexico, Antilles and Brazil (Fernando de Noronha and from Pará to São Paulo) (Barreto et al., 1993; Melo, 1996; CoelhoFilho, 2006).

Microphrys antillensis Rathbun, 1901 - Geographic distribution: Western Atlantic - North Carolina, Florida, Gulf of Mexico,
Antilles and Brazil (from Paraíba to Sáo Paulo) (Melo, 1996; Camargo et al., 2010).

Microphrys bicornutus (Latreille, 1825)

- Geographic distribution: Western Atlantic - From North Carolina to south of Florida, Bermuda, Gulf of Mexico, Antilles, Central America, Venezuela and Brazil (Rocas, Fernando de Noronha and from Maranháo to Rio Grande do Sul) (Fausto-Filho, 1967; Melo, 1996).

Microphrys garthi (Lemos de Castro, 1953) - Geographic distribution: Western Atlantic - Brazil (from Paraíba to Rio de 
Janeiro) (Melo, 1996).

Microphrys interruptus Rathbun, 1920 - Geographic distribution: Western Atlantic - Antilles and Brazil (Fernando de Noronha and from Maranhão to Alagoas) (Barretos et al., 1993; Melo, 1996).

Mithraculus coryphe (Herbst, 1801) Geographic distribution: Western Atlantic - Florida, Gulf of Mexico, Antilles, north of South America and Brazil (Fernando de Noronha and from Ceará to São Paulo) (Melo, 1996).

Mithraculus forceps A. Milne-Edwards, 1875 - Geographic distribution: Western Atlantic - From North Carolina to south of Florida, Bermuda, Gulf of Mexico, Antilles, Venezuela and Brazil (Fernando de Noronha, Rocas, Archipelago of the São Pedro-São Paulo and from Maranhão to São Paulo) (Melo, 1998; Nizinski, 2003; Viana et al., 2004).

Mithraculus sculptus (Lamarck, 1818)

- Geographic distribution: Western Atlantic - Florida, Gulf of Mexico, Antilles and Brazil (Fernando de Noronha and from Rio Grande do Norte to Bahia and São Paulo) (Miers, 1886; Melo, 1996; Camargo et al., 2010).

Mithrax besnardi Melo, 1990 Geographic distribution: Western Atlantic Brazil (Rio Grande do Sul) (Melo, 1996).

Mithrax braziliensis Rathbun, 1892 Geographic distribution: Western Atlantic Brazil (from Piauí to São Paulo) (Melo, 1998; Mantelatto et al., 2004).

Mithrax hemphilli Rathbun, 1892 Geographic distribution: Western Atlantic Florida, Antilles and Brazil (Rocas and from Maranhão to Rio de Janeiro) (Melo, 1996).

Mithrax hispidus (Herbst, 1790) Geographic distribution: Western Atlantic From Delaware to south of Florida, Bermuda, Gulf of Mexico, Bahamas, Antilles, Colombia and Brazil (from Amapá to São Paulo and Santa Catarina) (Melo, 1998; Silva et al., 1998; Rieger and Giraldi, 2001; Nizinski, 2003).

Mithrax tortugae Rathbun, 1920 Geographic distribution: Western Atlantic - Florida, Antilles, Colombia, Venezuela and Brazil (Pará, Pernambuco, Alagoas and from Bahia to São Paulo and Santa Catarina)
(Coelho et al., 1990; Melo, 1998; Rieger and Giraldi, 2001; Coelho et al., 2002; Almeida and Coelho, 2008).

Mithrax verrucosus $\mathrm{H}$. Milne Edwards, 1832 - Geographic distribution: Western Atlantic - South Carolina, Florida, Gulf of Mexico, Curacao, Antilles, Venezuela and Brazil (Fernando de Noronha, Rocas and São Paulo) (Melo, 1998; Nizinski, 2003; Alves et al., 2006).

Nemausa acuticornis (Stimpson, 1871) - Geographic distribution: Western Atlantic - From North Carolina to Florida, Gulf of Mexico, Antilles and Brazil (Fernando de Noronha, Rocas and from Amapá to São Paulo) (Melo, 1998; Coelho-Filho, 2006; Alves et al., 2006).

Nemausa cornuta (Saussure, 1857) Geographic distribution: Western Atlantic Bermuda, Florida, Gulf of Mexico, Antilles and Brazil (Fernando de Noronha, Rocas and from Amapá to Espírito Santo) (Melo, 1998; Coelho-Filho, 2006; Serejo et al., 2006).

Picroceroides tubularis Miers, 1886 Geographic distribution: Western Atlantic: Florida, Gulf of Mexico and Brazil (Fernando de Noronha, Rocas, from Amapá to Alagoas, Bahia and Espírito Santo) (Coelho, 1971; Fausto-Filho and Sampaio-Neto, 1976; Miers, 1886; Barreto et al., 1993; Coelho, 1969; Melo, 1996; Coelho-Filho, 2006).

Stenocionops furcatus (Olivier, 1791) Geographic distribution: Western Atlantic - Georgia, Florida, Gulf of Mexico, Antilles, Colombia and Brazil (from Ceará to Rio Grande do Sul) (Melo, 1996).

Stenocionopsspinimanus (Rathbun, 1892) - Geographic distribution: Western Atlantic - From North Carolina to Florida, Gulf of Mexico and Brazil (Fernando de Noronha, Pará, Rio Grande do Norte, São Paulo and Rio de Janeiro) (Melo, 1998; Sankarankutty et al., 1998; Viana et al., 2003; Alves et al., 2008).

Stenocionops spinosissimus (Saussure, 1857) - Geographic distribution: Western Atlantic - From North Carolina to Florida, Gulf of Mexico, Antilles, Brazil (Fernando de Noronha, Amapá and from Rio Grande do Norte to Rio Grande do Sul) and Uruguay 
(Melo, 1996; Viana et al., 2003).

Teleophrys ornatus Rathbun, 1901 Geographic distribution: Western Atlantic Gulf of Mexico, Antilles and Brazil (Fernando de Noronha, Bahia and São Paulo) (Gouvêa, 1986; Melo, 1998; Alves et al., 2006).

Teleophrys pococki Rathbun, 1892 Geographic distribution: Western Atlantic Curaçao and Brasil (Fernando de Noronha, Pernambuco, Alagoas and Bahia) (Gouvêa, 1986; Melo, 1998).

Thoe aspera Rathbun, 1901 - Geographic distribution: Western Atlantic - Porto Rico and Brasil (Pernambuco and Alagoas) (Melo, 1996).

The largest numbers of species have been recorded in the states of Pernambuco (26), Alagoas (26) and Bahia (25). In contrast, only three species of mithracines have been recorded in the state of Paraná. Among oceanic islands, the largest number of species (19) has been reported from Fernando de Noronha, and only one species, $M$. forceps from the São Pedro-São Paulo Archipelago (Fig. 2).

The dendrogram indicated three groups (A, B, and C) (Fig. 3). The "A" group was represented by the states of Paraná, Santa Catarina and Rio Grande do Sul, showing $15 \%$ similarity with the "B" or "C" groups.

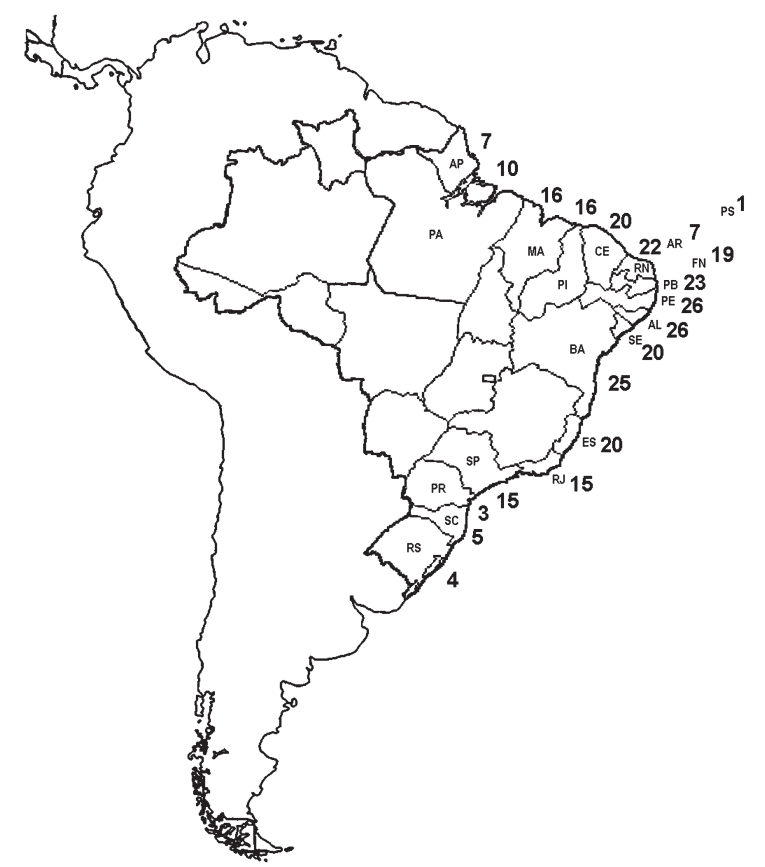

Figure 2. Number of species of Mithracinae by state along the Brazilian coast. For abbreviations see Table 1.
The "C" group was represented by the states of Amapá and Pará, showing about 20\% similarity with the "B" group, which consisted of the remaining coastal states (Fig. 3).

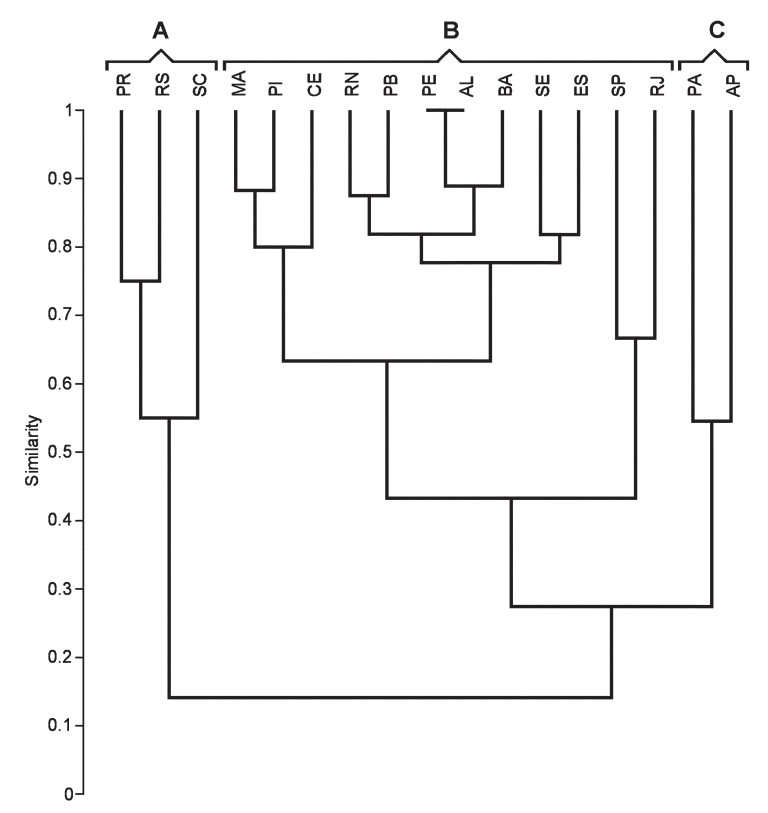

Figure 3. Cluster dendrogram (UPGMA - Jaccard), similarity between species occurrence by state along the Brazilian coast. Legend: Group A: PR = Paraná; SC = Santa Catarina; RS = Rio Grande do Sul; Group B: $\mathrm{MA}=$ Maranhão; $\mathrm{PI}=$ Piauí; $\mathrm{CE}=$ Ceará; $\mathrm{RN}=$ Rio Grande do Norte; $\mathrm{PB}=$ Paraíba; $\mathrm{PE}=$ Pernambuco; $\mathrm{AL}=$ Alagoas $; \mathrm{SE}=$ Sergipe $; \mathrm{BA}=$ Bahia $; \mathrm{ES}=$ Espírito Santo; RJ = Rio de Janeiro; $S P$ = São Paulo; Group C: $\mathrm{AP}=$ Amapá; $\mathrm{PA}=$ Pará.

\section{Discussion}

This review revealed that 17 species (M. camptocerum, $M$. laevigatum, $M$. septemspinosum, $M$. trispinosum, $M$. antillensis, M. forceps, M. sculptus, M. braziliensis, M. hispidus, $M$. tortugae, M. verrucosus, $N$. acuticornis, $N$. cornuta, P. tubularis, $S$. spinimanus, S. spinosissimus and T. ornatus) of Mithracinae have had their distributional limits enlarged along the Brazilian coast during the last two decades. Some of these records must be interpreted as expectable, because they extended the distribution to neighboring areas, and also the absence of barriers or filters could prevent the natural dispersal of a species (e.g., M. camptocerum, N. acuticornis 
and S. spinimanus). This find reinforces the notion that more studies are needed to really understand the distribution of these species. The discussion on the geographic distribution and mainly on the latitudinal pattern of the Mithracinae diversity was based on current knowledge and should be treated as testable hypothesis.

Other species, such as M. sculptus, $M$. verrucosus and $T$. ornatus, were recorded for new biogeographical province, (Argentinean province) for which these crabs have no previous records, suggesting that these species were able to cross zones of biogeographical barriers or filters. According to Boschi's (2000) characterization of the Brazilian coast, the Cabo Frio region (northeastern coast of Rio de Janeiro) is considered as a biogeographical barrier for decapods, preventing the southward dispersal of thermophilic species. Cabo Frio region seems to represent an effective biogeographical barrier for some genera of Mithracinae, especially Macrocoeloma Miers, 1879. Of the seven species in this genus, only $M$. trispinosum could enter in this coldwater upwelling zone. However, many other factors could be responsible for limiting the distribution of a few of these species, such as a gradual decrease in water temperature towards the south of Brazil and biotic relationships, e.g. competition and predation.

From the southern coast of São Paulo, the richness of Mithracinae decreases considerably, and the coasts of Paraná, Santa Catarina and Rio Grande do Sul show only about 45\% similarity of mithracine species to other sites along the Brazilian coast. This reinforces: 1) the hypothesis that there are distinct composition and richness patterns for mithracine species north and south of the Cabo Frio upwelling zone; 2) other factors may limit the geographic distribution of a few of these species; 3 ) some states along the Brazilian coast need more studies, e.g. the diversity of mithracines in Paraná and Santa Catarina is probably greater than what is currently known.

The mouth of the Amazon River also seems to act as an effective biogeographical barrier for most mithracines, with the number of species markedly decreasing on the northern Piauí coast, reinforced by the low similarity between Amapá and Pará: about $40 \%$ compared to other parts of the Brazilian Province. Although Boschi (2000) did not consider the Amazon River mouth as a barrier for decapods as a whole, a review of a small taxonomic group may reveal the variable effectiveness of a barrier, as suggested by MeloFilho (1997). This seems to be the case for the species of Mithracinae, which are exclusively marine and thereby possibly limited by the Amazon freshwater discharge. Those regions where biogeographical barriers occur are characterized by large environmental changes, resulting in faunistic transition zones with low rates of endemism, and hosting a mixed fauna from adjacent provinces (Ekman, 1953; Knox, 1960).

Despite the evidence of the Amazon River mouth as a barrier, based on the low richness of Mithracinae in this area, most species of this subfamily are recorded both north and south of the river mouth. The question thus arises as to how the Amazon River mouth can be viewed as a barrier for these crabs. Moreover, considering it is common sense that the Caribbean is the probable center of dispersal for this subfamily, how and when were these species able to cross this barrier, colonizing areas south of the Amazon River?

Fossil records of Majidae date from the Upper Cretaceous and Eocene (Spears et al., 1992). Tectonic movements in the northeastern Andes that influenced the present drainage of the Amazon River are known only from the Tertiary, during the late Miocene (Hoorn et al., 1995). An hypothesis to explain the present distribution of the mithracine species, with nearly the same assemblage present both north and south of the Amazon River mouth, suggests that these crabs must have dispersed along the Brazilian coast before the late Miocene, before the establishment of the Amazon River mouth barrier.

The low richness of Mithracinae recorded for the oceanic islands may be explained by the relatively small research effort targeted to crabs from these zones that may 
have resulted in underestimation of a number of species. This suggestion also reinforces the urgency of establishing monitoring programs in these areas, as well as employing alternative sampling techniques such as scuba diving or baited traps already used in many projects. In addition, studies on the composition and temporal dynamics of the plankton are needed to investigate whether the cited areas should be considered as biogeographic barriers, which certainly will contribute to updating the Brazilian marine fauna, as well as clarifying the factors that drive the distribution patterns of the mithracine crabs.

\section{Acknowledgments}

We are indebted to Dr. Gustavo Augusto Schmidt de Melo for his helpful suggestions during the development of this study, and we also appreciate the helpful comments by Drs. Maria Lucia Negreiros-Fransozo and Adilson Fransozo. We thank Dione Seripierri, chief librarian of the Museum of Zoology, Universidade de Sáo Paulo (MZUSP) for her help during the literature review and the anonymous reviewers for their comments and suggestions on the manuscript.

\section{References}

Almeida, A.O. and Coelho, P.A. 2008. Estuarine and marine brachyuran crabs (Crustacea: Decapoda) from Bahia, Brazil: checklist and zoogeographical considerations. Latin American Journal of Aquatic Research, 36(2): 183-222.

Almeida, A.O.; Coelho, P.A. and Santos, J.T.A. 2003. New records of decapod crustaceans Dendrobranchiata and Brachyura) for the state of Bahia, Brazil. Nauplius, 11(2): 129133.

Alves, D.F.R.; Cobo, V.J. and Melo, G.A.S. 2006. Extension of the geographical distribution of some brachyuran and porcellanid decapods (Crustacea) to the coast of the State of Sáo Paulo. Revista Brasileira de Zoologia, 23(4): 1280-1283.

Alves, M.L.; Ramos-Porto, M. and Viana, G.F.S. 2008. Checklist of the Decapods (Crustacea) from the Fernando de Noronha Archipelago, Brazil. Zootaxa, 1881: 43-68.

Barreto, A.V.; Coelho, P.A. and Ramos-Porto, M. 1993. Distribuição geográfica dos Brachyura (Crustacea, Decapoda) coletados na plataforma continental do Norte e Nordeste do Brasil. Revista Brasileira de Zoologia, 10(4): 641-656.

Bezerra, L.E.A.; Almeida, A.O. and Coelho, P.A. 2005. Primeiro registro de Apiomithrax violaceus (A. Milne-Edwards) e Hypoconcha arcuata Stimpson (Crustacea, Decapoda, Brachyura) para o litoral do Ceará, Brasil. Revista Brasileira de Zoologia, 22(4): 919922.

Boschi, E.E. 2000. Species of Decapod Crustaceans and their distribution in the American marine zoogeographic provinces. Revista de Investigación y Desarrollo Pesquero, 13: 7-136.

Camargo, F.V.; Alves, D.F.R. and Cobo, V.J. 2010. Range extensions for three majoid crabs (Crustacea, Decapoda, Brachyura) on the coast of São Paulo state, Brazil. PanAmerican Journal of Aquatic Sciences, 5(1): 169-172.

Castro-Filho, B. and Miranda, L.B. 1998. Physical oceanography of the western Atlantic continental shelf located between $4{ }^{\circ} \mathrm{N}$ and $34^{\circ} \mathrm{S}$ coastal segment $(4 \mathrm{oW})$. p. 209-251. In: A.R. Robinson and K.H. Brink (eds), The sea, Vol. 11. New York, John Wiley \& Sons.

Cobo, V.J.; Pinheiro, A.P.; Freire, F.A.M. and Martins, I.A. 2002. Range extension of the geographic distribution of the lobsters (Palinuroidea) and crabs (Xanthoidea) in the Brazilian coast. Nauplius, 10(2): 155158.

Coelho, P.A. 1969. A distribuição dos crustáceos decápodos reptantes do Norte do Brasil. Trabalhos Oceanográficos da Universidade Federal de Pernambuco, 9/11(1967/69): 223-238. 
Coelho, P.A. 1971. Nota prévia sobre os Majidae do Norte e Nordeste do Brasil (Crustacea, Decapoda). Arquivos do Museu Nacional, 54: 137-143.

Coelho, P.A.; Ramos-Porto, M. and Melo, G.A.S. 1990. Crustáceos decápodos do estado de Alagoas. Anais da Sociedade Nordestina de Zoologia, 3(3): 21-34.

Coelho, P.A.; Coelho-Santos, M.A.; Torres, M.F.A.; Monteiro, B.R. and Almeida, V.A.K. 2002. Reino Animalia: Filo (ou Subfilo) Crustacea no Estado de Pernambuco. pp. 429-482. In: M. Tabarelli and J.M.C. Silva (eds), Diagnóstico da biodiversidade de Pernambuco, Vol. 2. Recife, Massangana.

Coelho-Filho, P.A. 2002. Crustáceos decápodos, isópodos e estomatópodos da plataforma continental externa e bancos oceânicos do Nordeste do Brasil (Programa REVIZEE - NE III). Doctoral Thesis. Universidade de São Paulo, Instituto Oceanográfico, 149p.

Coelho-Filho, P.A. 2006. Checklist of the Decapods (Crustacea) from the outer continental shelf and seamounts from Northeast of Brazil - REVIZEE Program (NE III). Zootaxa, 1184: 1-27.

Ekman, S. 1953. Zoogeography of the sea. London, Sidgwick \& Jackson, 417p.

Fausto-Filho, J. 1967. Segunda contribuição ao inventário dos crustáceos decápodos marinhos do Nordeste Brasileiro. Arquivos da Estação de Biologia Marinha da Universidade Federal do Ceará, 7(1): 11-14.

Fausto-Filho, J. and Sampaio-Neto, J.B.S. 1976. Observaçóes sobre alguns crustáceos estomatópodos e decápodos do norte do Brasil. Arquivos de Ciências do Mar, 16(2): 65-71.

Fransozo,A.; Negreiros-Fransozo, M.L.; Mantelatto, F.L.; Pinheiro, M.A.A. and Santos S. 1992. Composição e distribuição dos Brachyura (Crustacea, Decapoda) do substrato não consolidado da Enseada da Fortaleza, Ubatuba (SP). Revista Brasileira de Biologia, 52(4): 667-675.

Gouvêa, E.P. 1986. A carcinofauna do litoral rochoso de Salvador, BA, e alguns aspectos ecológicos. Ciência e Cultura, 38(2): 346354.

Hedgpeth, J.W. 1957. Marine biogeography. p. 359-382. In: J.W. Hedgpeth (ed), Treatise on marine ecology and paleontology, Vol. 1. New York, Geological Society of America Memoir.

Holthuis, L.B. 1991. Marcgraf s (1648) Brazilian Crustacea. Zoologische Verhandenlingen, 31(268): 1-123.

Hoorn, C.; Guerrero, J.; Sarmiento, G.A. and Lorente, M.A. 1995. Andean tectonics as a cause for changing drainage patterns in Miocene northern South America. Geology, (23): 237-240.

Ikeda, Y. 1976. Variações em escala média da temperatura e da salinidade do mar na região entre a Baía de Guanabara e Cabo Frio (17/08 a 26/08/1971). Boletim do Instituto Oceanográfico de São Paulo, 25: 221-280.

Ikeda, Y.; Miranda, L.B. and Rock, N.J. 1974. Observations on stages of upwelling in the region of Cabo Frio (Brazil) as conducted by continuous surface temperature and salinity measurements. Boletim do Instituto Oceanográfico de São Paulo, 23: 33-46.

Knox, G.A. 1960. Littoral ecology and biogeography of the southern oceans. Proceedings of the Royal Society B-Biological Sciences, 152: 577-624.

Mantelatto, F.L.; Faria, F.C.R.; Biagi, R. and Melo, G.A.S. 2004. Majoid crabs community (Crustacea: Decapoda) from infralittoral rocky/sandy bottom of Anchieta Island, Ubatuba. Brazilian Archives of Biology and Technology, 47(2): 273-279.

Matsuura, Y. 1986. Contribuição ao estudo da estrutura oceanográfica da regiáo sudeste entre Cabo Frio (RJ) e Cabo de Santa Marta Grande (SC). Ciência e Cultura, 38(8): 1439-1450.

Melo, G.A.S. 1985. Taxonomia e padróes distribucionais e ecológicos dos Brachyura (Crustacea: Decapoda) do Litoral sudeste do Brasil. Doctoral Thesis. Universidade de São Paulo, Instituto de Biociências, 215p.

Melo, G.A.S. 1990. A presença, no litoral sudeste brasileiro, de espécies de Brachyura (Crustacea: 
Decapoda) originárias das regióes biogeográficas Magelânica e Argentina do Atlântico Sul. Atlântica, 12(2): 71-83.

Melo, G.A.S. 1996. Manual de identificação dos Brachyura (caranguejos e siris) do litoral brasileiro. São Paulo, Plêaide, 604p.

Melo, G.A.S. 1998. Malacostraca - Eucarida. Brachyura. Oxyrhyncha and Brachyrhyncha. p. 455-515. In: P.S. Young (ed), Catalogue of Crustacea of Brazil. Rio de Janeiro, Museu Nacional.

Melo, G.A.S.; Bertini, G. and Fransozo, A. 2000. Ocurrence of the eastern pacific species Pilumnoides perlatus (Poeppig, 1836) in the southeastern Brazilian coast. Nauplius, 8(1): 89-91.

Melo-Filho, G.A.S. 1997. O gênero Munida beach (Crustacea, Decapoda, Galatheidae) no Atlântico e Mediterrâneo: Composição e Biogeografia. Doctoral Thesis, Universidade de São Paulo, Instituto Biociências, 248p.

Miers, E.J. 1886. Report on the Brachyura collected by H.M.S. "Challenger" during the years 1873-1876. Report on the Scientific Results of the Voyage of H.M.S. "Challenger" During the Years 1873-1876. Zoology, 17(49):1-362.

Ng, P.K.L.; Guinot, D. and Davie, P.J.F. 2008. Systema brachyurorum: Part I. An annotated checklist of extant brachyuran crabs of the world. Raffles Bulletin of Zoology, 17: 1-286.

Nizinski, M.S. 2003. Annotated checklist of decapod crustaceans of Atlantic coastal and continental shelf waters of the United States. Proceedings of the Biological Society of Washington, 116(1): 96-157.

Nucci, P.R.; Melo, G.A.S.; Melo-Filho, G.A.S. and Campos-Júnior, O. 2004. Classe Malacostraca - Ordens Decapoda \& Stomatopoda. p. 136-140. In: A.C.Z. Amaral and C.L.B. Rossi-Wongtschowski (orgs), Biodiversidade bentônica da regiáo Sudeste-Sul do Brasil - Plataforma externa e Talude superior. Sáo Paulo, Instituto Oceanográfico.

Pinheiro, M.A.A.; Fransozo, A. and NegreirosFransozo, M.L. 1996. Distribution patterns of Arenaeus cribrarius (Lamarck, 1818)
(Crustacea, Brachyura, Portunidae), in Fortaleza Bay Ubatuba (SP), Brazil. Revista Brasileira de Biologia, 56(4): 705-716.

Ramos-Porto, M.; Torres, M.F.A.; Viana, G.F.S.; Santos, M.C.F.; Acioli, F.D. and Cabral, E. 2000. Registers of two species of Crustacea Decapoda Brachyura in the Brazilian Waters. Nauplius, 8(1): 169-171.

Ramos-Porto, M.; Torres, M.F.A.; Santos, M.C.F.; Viana, G.F.S.; Cabral, E. and Acioli, F.D. 2002. Ocorrência do gênero Acanthocarpus Stimpson, 1871 (Crustacea: Decapoda: Brachyura) em águas do nordeste brasileiro. Boletim TécnicoCientifico do CEPENE, 10(1): 97-106.

Rathbun, M.J. 1925. The spider crabs of America. Bulletin of the United States National Museum, 129: 1-613.

Rieger, P.J. and Giraldi, J.L.B. 2001. Mithrax hispidus (Herbst) e Mithrax tortugae Rathbun novos registros de Brachyura (Decapoda, Majidae) para o litoral de Santa Catarina, Brasil. Revista Brasileira de Zoologia, 18(2): 653-654.

Sankarankutty, C.; Oliveira, J.E.L.; Ferreira, A.C. and Cunha, K.M.F. 1998. On two spider crabs (Crustacea: Decapoda: Majidae) from the Northeast of Brazil. Nauplius, 6: 187-188.

Santos, S.; Negreiros-Fransozo, M.L. and Fransozo, A. 1994. The distribution of the swimming crab Portunus spinimanus Latreille, 1819 (Crustacea, Brachyura, Portunidae) in Fortaleza Bay, Ubatuba, SP, Brazil. Atlântica, 16: 125-141.

Serejo, C.; Young, O.S.; Cardoso, I.A., Tavares, C.R. and Abreu Jr., C.R. 2006. Filo Arthropoda. Subfilo Crustacea. p. 299-337. In: H.P. Lavrado and B.L. Ignacio (eds), Biodiversidade bentônica da regiāo central da Zona Econômica Exclusiva brasileira. Rio de Janeiro, Museu Nacional.

Silva, K.C.A.; Ramos-Porto, M.; Viana, G.F.S. and Cintra, I.H.A. 1998. Informações preliminares sobre os Brachyura (Crustacea: Decapoda) coletados na costa Norte do Brasil durante o Programa REVIZEE. Trabalhos Oceanográficos da Universidade Federal de Pernambuco, 26(1): 85-97.

Silva, K.C.A.; Ramos-Porto, M. and Cintra, I.H.A. 2001. Caranguejos capturados durante pescarias 
experimentais para o Programa REVIZEE/Norte (Crustacea: Decapoda: Brachyura). Boletim Técnico-Científico do CEPNOR, 1:77-102.

Silva, J.S.V.; Fernandes, F.C.; Souza, R.C.C.L.; Larsen, K.T.S. and Danelon, O.M. 2004. Água de Lastro e Bioinvasão. p. 1-10. In: J.S.V. Silva and R.C.C.L. Souza (eds), Água de Lastro e Bioinvasão. Rio de Janeiro, Interciência.

Spears, T.; Abele, L.G. and Kim, W. 1992.

The monophyly of Brachyuran Crabs: a phylogenetic study based on $18 \mathrm{~S}$ rRNA. Systematic Biology, 41(4): 446-461.

Targino, S.G.; Campos, C.E.C.; Silva, M.B.; Melo, C.E.D.C.A. and Macêdo, G.D. 2001. First record of the mangrove crab Goniopsis cruentata (Latreille, 1803) (Brachyura: Grapsidae) in Atol das Rocas, Brazil. Nauplius, 9(2): 169-170.

Tavares, M. and Amouroux, J.M. 2003. First Record of the non-indigenous crab, Charybdis hellerii (A. Milne-Edwards, 1867) from French Guyana (Decapoda, Brachyura, Portunidae). Crustaceana, 76(5): 625-630.

Torres, M.F.A.; Santos, M.C.F.; Viana, G.F.S.; Ramos-Porto, M.; Acioli, F.D. and Cabral, E. 2002. Registro de Myropsis quinquespinosa Stimpson, 1871 (Crustacea, Decapoda, Leucosiidae) no nordeste brasileiro. Boletim Técnico-Cientifico do CEPENE, 10(1): 107114.

Viana, G.F.S.; Ramos-Porto, M.; Torres, M.F.A.; Santos, M.C.F.; Cabral, E. and Acioli, F.D. 2002. Espécies de Rochinia A. Milne-Edwards, 1875 (Decapoda: Brachyura: Majidae) coletadas em águas do nordeste brasileiro. Boletim TécnicoCientifico do CEPENE, 10(1): 85-96.

Viana, G.F.S.; Ramos-Porto, M.; Santos, M.C.F.; Silva, K.C.A.; Cintra, I.H.A.; Cabral, E.; Torres, M.F.A. and Acioli, F.D. 2003. Caranguejos coletados no norte e nordeste do Brasil durante o programa REVIZEE (Crustacea, Decapoda, Brachyura). Boletim Técnico-Cientifico do CEPENE, 11(1): 117-144.

Viana, G.F.S.; Ramos-Porto, M. and Torres, M.F.A. 2004. Crustáceos decápodos coletados no Arquipélago de São Pedro e São Paulo, Brasil. Boletim Técnico-Cientifico do CEPENE, 12(1): 43-50.

Windsor, A.M. and Felder, D.L. 2009. Re- evaluation of species allied to Mithrax hispidus (Decapoda: Brachyura: Majoidea: Mithracidae) based on three mitochondrial genes. Zootaxa, 2302: 61-68.

Windsor, A.M. and Felder, D.L. 2011. A new species of Hemus (Majoidea: Majidae: Mithracinae) from the Pacific coast of Panamá, with a key to the genus. Zootaxa, 2799: 63-68.

Zar, J.H. 2010. Biostatistical analysis, $5^{\text {th }}$ edition. New Jersey, Prentice-Hall, 944p. 